\title{
Humihabitans oryzae gen. nov., sp. nov.
}

Correspondence
Yoko Takahashi
ytakaha@lisci.kitasato-u.ac.jp

\author{
Akiko Kageyama, ${ }^{1}$ Yoko Takahashi ${ }^{1}$ and Satoshi Ōmura ${ }^{1,2}$ \\ ${ }^{1}$ Kitasato Institute for Life Sciences, Kitasato University, 5-9-1 Shirokane, Minato-ku, \\ Tokyo 108-8641, Japan \\ ${ }^{2}$ The Kitasato Institute, 5-9-1 Shirokane, Minato-ku, Tokyo 108-8641, Japan
}

\begin{abstract}
Strain $\mathrm{KV}-657^{\top}$ was isolated from a paddy field soil sample collected in Japan using GPM agar plates supplemented with catalase. The strain was a Gram-positive, aerobic organism that formed branching hyphae with LL-diaminopimelic acid as the diagnostic peptidoglycan diamino acid. The major menaquinone was MK- $8\left(\mathrm{H}_{4}\right)$. Mycolic acids were not detected. The $\mathrm{G}+\mathrm{C}$ content of the DNA was 70 mol\%. 16S rRNA gene sequence analysis revealed that this strain is closely related to Intrasporangium calvum DSM $43043^{\top}$, with a similarity of $97.6 \%$. Based on the morphological, biochemical and chemotaxonomic properties of this strain and phylogenetic analysis, it was concluded that this isolate represents a new genus and species in the family Intrasporangiaceae, for which the name Humihabitans oryzae gen. nov., sp. nov. is proposed. The type strain of Humihabitans oryzae is KV-657 $7^{\top}\left(=\mathrm{NRRL} \mathrm{B-} 24470^{\top}=\mathrm{NBRC} 101802^{\top}\right)$.
\end{abstract}

In order to facilitate the discovery of novel microorganisms, various isolation techniques have been developed (Magarvey et al., 2004; Yamamura et al., 2003; Hayakawa et al., 2004). In a previous report, we described a new isolation method using agar medium containing oxidant scavengers, for example superoxide dismutase with or without catalase (Takahashi et al., 2003). Using this method, we have succeeded in isolating representatives of two new genera, Oryzihumus leptocrescens (Kageyama et al., 2005) and Patulibacter minatonensis (Takahashi et al., 2006). Among 45 strains isolated from paddy soil in Saitama Prefecture, Japan, using this new isolation method (Takahashi et al., 2003), 20 strains belonged to the class Actinobacteria, including strain $\mathrm{KV}-657^{\mathrm{T}}$. Strain $\mathrm{KV}-657^{\mathrm{T}}$ forms branching hyphae, has LL-diaminopimelic acid $\left(\mathrm{A}_{2} \mathrm{pm}\right)$ in its peptidoglycan and, on the basis of a phylogenetic tree constructed using 16S rRNA gene sequences, it was thought to be closely associated with Intrasporangium calvum.

In this paper, we report on the morphological, physiological and biochemical characteristics of strain $\mathrm{KV}-657^{\mathrm{T}}$ and DNA-DNA hybridization and $16 \mathrm{~S}$ rRNA gene sequence analysis in comparison with I. calvum NBRC $12989^{\mathrm{T}}$. Based on these results, $\mathrm{KV}-657^{\mathrm{T}}$ represents a novel genus and species.

Abbreviation: $A_{2}$ pm, diaminopimelic acid.

The GenBank/EMBL/DDBJ accession number for the 16S rRNA gene sequence of strain $\mathrm{KV}-657^{\top}$ is $\mathrm{AB} 282887$.

Scanning electron micrographs of cells of strain $\mathrm{KV}-657^{\top}$ and HPLC traces from menaquinone analysis of the novel strain and $I$. calvum NBRC $12989^{\top}$ are available as supplementary material with the online version of this paper.
Strain $\mathrm{KV}-657^{\mathrm{T}}$ was isolated from soil samples collected from a paddy field in Saitama Prefecture, Japan. Biomass for biochemical and chemotaxonomic studies was prepared by culture in TSB (Difco) at $27{ }^{\circ} \mathrm{C}$ for 3 or 4 days, followed by harvesting by centrifugation.

Morphological observations were carried out using a scanning electron microscope (model JSM-5600; JEOL) and cultures grown on GPM agar medium ( $1 \%$ D-glucose, $0.5 \%$ peptone, $0.5 \%$ meat extract, $0.3 \% \mathrm{NaCl}$ and $1.2 \%$ agar; $\mathrm{pH} 7.0$ ) at $27{ }^{\circ} \mathrm{C}$ for 2 days. The ability of the strain to grow on a range of sole carbon sources at $1 \%(\mathrm{w} / \mathrm{v})$ was determined using carbon utilization media (Pridham \& Gottlieb, 1948) (Nihon Pharmaceutical Co., Ltd). NaCl tolerance $(0-7 \%)$ and $\mathrm{pH}(3-11)$ and temperature (5$45{ }^{\circ} \mathrm{C}$ ) ranges for growth were determined on 1/5-strength nutrient agar. The isolate was characterized biochemically using API ZYM in accordance with the manufacturer's instructions (bioMérieux).

Whole-cell hydrolysates were analysed for $\mathrm{A}_{2} \mathrm{pm}$ isomers using TLC (Becker et al., 1965; Hasegawa et al., 1983). Purified cell walls were obtained by using the method of Kawamoto et al. (1981). One milligram of purified cell wall was hydrolysed at $100{ }^{\circ} \mathrm{C}$ with $1 \mathrm{ml} 6 \mathrm{M} \mathrm{HCl}$ for $16 \mathrm{~h}$. The residue was dissolved in $100 \mu \mathrm{l}$ water and this solution was used for amino acid analysis. Amino acid composition was determined by HPLC using the Pico Tag method (Waters). Samples were derivatized with phenylisothiocyanate and UV detection (at $254 \mathrm{~nm}$ ) was used. The presence of mycolic acids was assessed by using the TLC method of Tomiyasu (1982). Menaquinones were extracted and purified by using the method of Collins et al. (1977) and then analysed by HPLC (model 802-SC; Jasco) using a chromatograph equipped with a Capcell Pak C18 column 


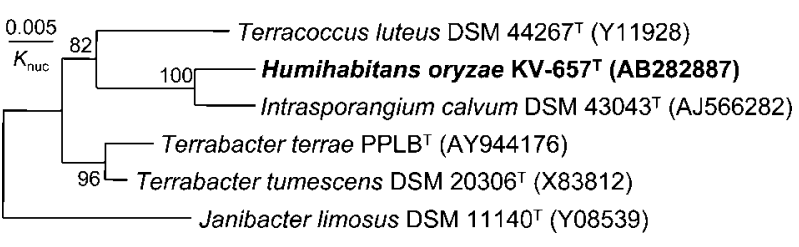

Fig. 1. Phylogenetic tree constructed on the basis of $16 \mathrm{~S}$ rRNA gene sequences, using the neighbour-joining method and $K_{\text {nuc }}$ values. Janibacter limosus DSM $11140^{\top}$ was used as an outgroup. GenBank accession numbers are given in parentheses. Numbers at nodes indicate percentages of bootstrap support based on a neighbour-joining analysis of 1000 resampled datasets. Bar, 0.005 substitutions per nucleotide position.

(Shiseido) (Tamaoka et al., 1983). Methyl esters of cellular fatty acids were prepared and analysed by GLC (model HP6890; Hewlett Packard).

DNA for determination of base composition and DNADNA relatedness values was isolated as described by Saito \& Miura (1963), with some modifications. The DNA base composition was estimated by HPLC (Tamaoka \& Komagata, 1984). Levels of DNA-DNA relatedness were determined by using the method of Ezaki et al. (1989), using photobiotin and a microplate format.

DNA for PCR was prepared by sonication (Yu et al., 2002). The 16S rRNA gene was amplified by PCR and sequenced using an automatic sequence analyser (ABI Prism 3130; PE Applied Biosystems) using a dye terminator cycle-sequencing kit (PE Applied Biosystems).

Species related to the new isolate were identified by performing sequence database searches using BLAST. Sequence data for related species were retrieved from GenBank. Nucleotide substitution rates ( $K_{\text {nuc }}$ values) were calculated (Kimura \& Ohta, 1972) and phylogenetic trees were constructed by using the neighbour-joining method (Saitou \& Nei, 1987). The statistical significance of the tree topology was evaluated by bootstrap analysis of sequence data using CLUSTAL W software (Thompson et al., 1994). Sequence similarity values were determined by visual comparison and manual calculation.
A nearly complete $16 \mathrm{~S}$ rRNA gene sequence was determined for strain $\mathrm{KV}-657^{\mathrm{T}}$. A database search demonstrated that the strain belonged to the family Intrasporangiaceae. The phylogenetic tree was calculated using 16S rRNA gene sequence data as follows: I. calvum DSM $43043^{\mathrm{T}}$ (1469 bp), Terracoccus luteus DSM $44263^{\mathrm{T}}$ (1479 bp), Terrabacter terrae $\operatorname{PPLB}^{\mathrm{T}}$ (1475 bp) and Terrabacter tumescens DSM $20306^{\mathrm{T}}(1461 \mathrm{bp})$. In the $16 \mathrm{~S}$ rRNA gene phylogenetic tree (Fig. 1), the strain was closely associated with I. calvum DSM $43043^{\mathrm{T}}$. The sequence similarity between $\mathrm{KV}-657^{\mathrm{T}}$ and I. calvum DSM $43043^{\mathrm{T}}$ was $97.6 \%$.

The novel strain was also examined for a set of phenotypic and chemotaxonomic characteristics. The strain formed branching hyphae and also fragmentary hyphae. Cell length varied from 1.0 to $2.2 \mu \mathrm{m}$, with a mean diameter of around $0.5 \mu \mathrm{m}$ (see Supplementary Fig. S1 in IJSEM Online). The cells were Gram-positive and catalase-positive. The DNA base composition of $\mathrm{KV}-657^{\mathrm{T}}$ was $70 \mathrm{~mol} \% \mathrm{G}+\mathrm{C}$ according to the HPLC nucleoside method. The cell-wall peptidoglycan of $\mathrm{KV}-657^{\mathrm{T}}$ contained LL-A 2 pm, Ala, Gly and Glu and was of type A3 $\gamma$ (Schleifer \& Kandler, 1972). The predominant menaquinone was MK- $8\left(\mathrm{H}_{4}\right)$. Mycolic acids were not detected. The cellular fatty acid components were iso- $\mathrm{C}_{14: 0}(7.3 \%)$, iso- $\mathrm{C}_{15: 0}(39.6 \%)$, anteiso- $\mathrm{C}_{15: 0}$ $(5.8 \%), \mathrm{C}_{15: 0}(4.8 \%)$, iso- $\mathrm{C}_{16: 0}(13.3 \%)$, iso- $\mathrm{C}_{17: 0}(2.0 \%)$, anteiso- $\mathrm{C}_{17: 0}(2.0 \%), \mathrm{C}_{17: 0} \omega 8 c(6.4 \%)$ and $\mathrm{C}_{17: 0}(5.8 \%)$.

In order to confirm that the strain belonged to a novel species, DNA-DNA hybridization relatedness was determined. The level of DNA-DNA relatedness between the isolated strain and I. calvum NBRC $12989^{\mathrm{T}}$ was determined to be $33-34 \%$, which was well below the $70 \%$ cut-off point for species classification recommended by Wayne et al. (1987).

The differential characteristics of strain $\mathrm{KV}-657^{\mathrm{T}}$ and other LL- $\mathrm{A}_{2} \mathrm{pm}$-containing members of the family Intrasporangiaceae are listed in Table 1. The major cellular fatty acids of these isolates are a complex mixture of straight-chain saturated, monounsaturated, iso- and anteiso-methylbranched acids. Members of the genus Arsenicicoccus have a similar complex of major cellular fatty acids, but differ in cell morphology. On the basis of the $16 \mathrm{~S}$ rRNA gene sequence-based phylogenetic tree, $\mathrm{KV}-657^{\mathrm{T}}$ is thought to

Table 1. Differential characteristics of strain $\mathrm{KV}-657^{\top}$ and other $\mathrm{LL}-\mathrm{A}_{2} \mathrm{pm}$-containing members of the family Intrasporangiaceae

Data for reference genera were taken from Collins et al. (2004) (Arsenicicoccus), Schumann et al. (1997) (Intrasporangium), Martin et al. (1997) (Terrabacter) and Groth et al. (2002) (Terracoccus).

\begin{tabular}{|c|c|c|c|c|c|}
\hline Characteristic & Strain $\mathrm{KV}-657^{\mathrm{T}}$ & Arsenicicoccus & Intrasporangium & Terrabacter & Terracoccus \\
\hline Cell morphology & Hyphae & Cocci & Hyphae & Cocci to rods & Cocci \\
\hline DNA G $+C$ content $(\mathrm{mol} \%)$ & 70 & 72 & 68 & $70-73$ & 73 \\
\hline Major menaquinone & $\mathrm{MK}-8\left(\mathrm{H}_{4}\right)$ & MK-8 $\left(\mathrm{H}_{4}\right)$ & MK-8 & MK-8 $\left(\mathrm{H}_{4}\right)$ & $\mathrm{MK}-8\left(\mathrm{H}_{4}\right)$ \\
\hline Fatty acid types ${ }^{\star}$ & SAIU & SAIU & SAI & SAI & SAI \\
\hline
\end{tabular}

${ }^{\star}$ A, Anteiso-methyl branched; I, iso-methyl branched; S, straight-chain saturated; U, monounsaturated. 
be closely related to the genus Intrasporangium, but can be differentiated by cell morphology and the major menaquinones (Supplementary Fig. S2). Our findings show that $\mathrm{KV}-657^{\mathrm{T}}$ belongs to new genus in the family Intrasporangiaceae.

Based on its distinct phylogenetic position within the family Intrasporangiaceae and the differential cell morphology, cell-wall murein type and fatty acid composition, the name Humihabitans oryzae gen. nov., sp. nov. is proposed.

\section{Description of Humihabitans gen. nov.}

Humihabitans (Hu.mi.ha'bi.tans. L. masc. n. humus soil; L. part. adj. habitans inhabiting; N.L. part. adj. used as a masc. n. Humihabitans inhabitant of soil).

Gram-positive, catalase-positive, aerobic organisms that form branching hyphae. Fragmentary vegetative mycelium is produced. Peptidoglycan is of the A type of direct crosslinkage and contains $\mathrm{LL}_{-} \mathrm{A}_{2} \mathrm{pm}$, glycine, alanine and glutamic acid. Mycolic acids are absent. The major menaquinone is MK- $8\left(\mathrm{H}_{4}\right)$. Phylogenetically, the genus is a member of the family Intrasporangiaceae. The type species is Humihabitans oryzae.

\section{Description of Humihabitans oryzae sp. nov.}

Humihabitans oryzae (o.ry'zae. L. gen. n. oryzae of rice, pertaining to the isolation of the type strain from rice paddy soil).

In addition to the characteristics that define the genus, it has the characteristics described below. Cell length is 1.0 $2.2 \mu \mathrm{m}$ with a mean diameter of around $0.5 \mu \mathrm{m}$. Colonies are pale yellow. Growth occurs at $\mathrm{pH} 5-11$ and at 8 and $40{ }^{\circ} \mathrm{C}$. In $1 / 5$-strength nutrient agar medium, $\mathrm{NaCl}$ is tolerated up to $3 \%$. D-Fructose, D-glucose, maltose, Dmannitol, D-mannose, sucrose, trehalose and D-xylose are assimilated, but L-arabinose, D-galactose, raffinose and $\mathrm{L}$ rhamnose are not. Esterase (C4), esterase lipase (C8), valine arylamidase, cystine arylamidase, trypsin, chymotrypsin, acid phosphatase, $\alpha$-galactosidase, $\beta$-galactosidase and $\alpha$ glucosidase are detected by the API ZYM enzyme assay; alkaline phosphatase, $\beta$-glucuronidase, $N$-acetyl- $\beta$-glucosaminidase, $\alpha$-mannosidase and $\alpha$-fucosidase are negative. Weak reactions for lipase (C14), leucine arylamidase, naphthol-AS-BI-phosphohydrolase and $\beta$-glucosidase are detected in API ZYM tests. The DNA G $+\mathrm{C}$ content of the type strain is $70 \mathrm{~mol} \%$.

The type strain, $\mathrm{KV}-657^{\mathrm{T}}$ (=NRRL B-24470 $0^{\mathrm{T}}=\mathrm{NBRC}$ $\left.101802^{\mathrm{T}}\right)$, was isolated from rice paddy soil in Japan.

\section{Acknowledgements}

This study was supported in part by a grant of the 21st Century COE Program from the Ministry of Education, Culture, Sports, Science and Technology (MEXT), and the JSPS Grant-in-Aid for Science Research Foundation.

\section{References}

Becker, B., Lechevalier, M. P. \& Lechevalier, H. A. (1965). Chemical composition of cell-wall preparations from strains of various formgenera of aerobic actinomycetes. Appl Microbiol 13, 236-243.

Collins, M. D., Pirouz, T., Goodfellow, M. \& Minnikin, D. E. (1977). Distribution of menaquinones in actinomycetes and corynebacteria. J Gen Microbiol 100, 221-230.

Collins, M. D., Routh, J., Saraswathy, A., Lawson, P. A., Schumann, P., Welinder-Olsson, C. \& Falsen, E. (2004). Arsenicicoccus bolidensis gen. nov., sp. nov., a novel actinomycete isolated from contaminated lake sediment. Int J Syst Evol Microbiol 54, 605-608.

Ezaki, T., Hashimoto, Y. \& Yabuuchi, E. (1989). Fluorometric deoxyribonucleic acid-deoxyribonucleic acid hybridization in microdilution wells as an alternative to membrane filter hybridization in which radioisotopes are used to determine genetic relatedness among bacterial strains. Int J Syst Bacteriol 39, 224-229.

Groth, I., Schumann, P., Schuetze, B., Augsten, K., Kramer, I. \& Stackebrandt, E. (2002). Knoellia sinensis gen. nov., sp. nov. and Knoellia subterranea sp. nov., two novel actinobacteria isolated from a cave. Int J Syst Evol Microbiol 52, 77-84.

Hasegawa, T., Takizawa, M. \& Tanida, S. (1983). A rapid analysis for chemical grouping of aerobic actinomycetes. J Gen Appl Microbiol 29, 319-322.

Hayakawa, M., Yoshida, Y. \& limura, Y. (2004). Selective isolation of bioactive soil actinomycetes belonging to the Streptomyces violaceusniger phenotypic cluster. J Appl Microbiol 96, 973-981.

Kageyama, A., Takahashi, Y., Seki, T., Tomoda, H. \& Ōmura, S. (2005). Oryzihumus leptocrescens gen. nov., sp. nov. Int J Syst Evol Microbiol 55, 2555-2559.

Kawamoto, I., Oka, T. \& Nara, T. (1981). Cell wall composition of Micromonospora olivoasterospora, Micromonospora sagamiensis, and related organisms. J Bacteriol 146, 527-534.

Kimura, M. \& Ohta, T. (1972). On the stochastic model for estimation of mutation distance between homologous proteins. J Mol Evol 2, 87-90.

Magarvey, N. A., Keller, J. M., Bernan, V., Dworkin, M. \& Sherman, D. H. (2004). Isolation and characterization of novel marine-derived actinomycete taxa rich in bioactive metabolites. Appl Environ Microbiol 70, 7520-7529.

Martin, K., Schumann, P., Rainey, F. A., Schuetze, B. \& Groth, I. (1997). Janibacter limosus gen. nov., sp. nov., a new actinomycete with meso-diaminopimelic acid in the cell wall. Int J Syst Bacteriol 47, 529-534.

Pridham, T. G. \& Gottlieb, D. (1948). The utilization of carbon compounds by some Actinomycetales as an aid for species determination. J Bacteriol 56, 107-114.

Saito, H. \& Miura, K. (1963). Preparation of transforming deoxyribonucleic acid by phenol treatment. Biochim Biophys Acta 72, 619-629.

Saitou, N. \& Nei, M. (1987). The neighbor-joining method: a new method for reconstructing phylogenetic trees. Mol Biol Evol 4, 406-425.

Schleifer, K. H. \& Kandler, O. (1972). Peptidoglycan types of bacterial cell walls and their taxonomic implications. Bacteriol Rev 36, 407-477.

Schumann, P., Prauser, H., Rainey, F. A., Stackebrandt, E. \& Hirsch, P. (1997). Friedmanniella antarctica gen. nov., sp. nov., an LL-diaminopimelic acid-containing actinomycete from Antarctic sandstone. Int $\mathrm{J}$ Syst Bacteriol 47, 278-283.

Takahashi, Y., Katoh, S., Shikura, N., Tomoda, H. \& Omura, S. (2003). Superoxide dismutase produced by soil bacteria increases 
bacterial colony growth from soil samples. J Gen Appl Microbiol 49, 263-266.

Takahashi, Y., Matsumoto, A., Morisaki, K. \& Ōmura, S. (2006). Patulibacter minatonensis gen. nov., sp. nov., a novel actinobacterium isolated using an agar medium supplemented with superoxide dismutase, and proposal of Patulibacteraceae fam. nov. Int J Syst Evol Microbiol 56, 401-406.

Tamaoka, J. \& Komagata, K. (1984). Determination of DNA base composition by reversed-phase high-performance liquid chromatography. FEMS Microbiol Lett 25, 125-128.

Tamaoka, J., Katayama-Fujimura, Y. \& Kuraishi, H. (1983). Analysis of bacterial menaquinone mixtures by high performance liquid chromatography. J Appl Bacteriol 54, 31-36.

Thompson, J. D., Higgins, D. G. \& Gibson, T. J. (1994). Clustal W: improving the sensitivity of progressive multiple sequence alignment through sequence weighting, position-specific gap penalties and weight matrix choice. Nucleic Acids Res 22, 4673-4680.

Tomiyasu, I. (1982). Mycolic acid composition and thermally adaptative changes in Nocardia asteroides. J Bacteriol 151, 828-837.

Wayne, L. G., Brenner, D. J., Colwell, R. R., Grimont, P. A. D., Kandler, O., Krichevsky, M. I., Moore, L. H., Moore, W. E. C., Murray, R. G. E. \& other authors (1987). International Committee on Systematic Bacteriology. Report of the ad hoc committee on reconciliation of approaches to bacterial systematics. Int J Syst Bacteriol 37, 463-464.

Yamamura, H., Hayakawa, M. \& limura, Y. (2003). Application of sucrose-gradient centrifugation for selective isolation of Nocardia spp. from soil. J Appl Microbiol 95, 677-685.

Yu, L., Takahashi, Y., Matsumoto, A., Seino, A., Iwai, Y. \& Omura, S. (2002). Application of PCR for selection of gram-positive bacteria with high DNA G $+C$ content among new isolates. Actinomycetologica 16, 1-5. 